\title{
Expression of the Immediate Early Gene $c$-fos in Basal Ganglia: Induction by Dopaminergic Drugs
}

\author{
H.A. Robertson, M.L. Paul, R. Moratalla and A.M. Graybiel
}

\begin{abstract}
Expression of the immediate early gene $c$-fos is increased in mammalian neurons by a number of stimuli and the usefulness of this gene as a marker of neuronal activation has been demonstrated in several systems. Directlyacting dopamine agonists of the D1-type (SKF 38393, CY 208-243) and indirectly-acting dopamine agonists (amphetamine, cocaine) all produce a rapid and transient increase in Fos protein levels in varying patterns in striatum and cerebral cortex. Directly-acting dopamine agonists only produce $c$-fos activation in denervated (supersensitive) striatum whereas cocaine and amphetamine activate $c-f o s$ in striatum in naive animals. Remarkably, D2 selective antagonists such as haloperidol, albeit in high doses, also activate $c$-fos expression. Activation of $c$-fos and other immediate early genes may play a part in the development of such long-term dopamine-related effects as dyskinetic movements and addiction.
\end{abstract}

\begin{abstract}
RÉSUMÉ: Expression du gène immédiat précoce $c$-fos dans les ganglions de la base : induction par les agents dopaminergiques. L'expression du gène précoce immédiat $c$-fos est augmentée dans les neurones des mammifères par un certain nombre de stimuli et l'utilité de ce gène comme marqueur de l'activation neuronale a été démontrée dans plusieurs systèmes. Des agonistes dopaminergiques de type DI (SKF 38393, CY 208-243) agissant directement et des agonistes dopaminergiques agissant indirectement (amphétamine, cocaïne) produisent tous une augmentation rapide et transitoire dans les niveaux de protéine Fos selon des patrons variés dans le striatum et le cortex cérébral. Des agonistes dopaminergiques agissant directement produisent seulement une activation de $c$-fos dans le striatum dénervé (hypersensible), alors que la cocaïne et l'amphétamine activent $c$-fos dans le striatum chez des animaux naïfs. Il est remarquable d'observer que des antagonistes sélectifs pour D2 tel l'halopéridol, administré à hautes doses, activent également l'expression de $c$-fos. L'activation de $c$-fos et d'autres gènes immédiats précoces peut jouer un rôle dans l'apparition d'effets à long terme reliés à la dopamine tels les mouvements dyskinétiques et la toxicomanie.
\end{abstract}

Can.J. Neurol. Sci. 1991; 18:380-383

Dopamine plays a pivotal role in the central regulation of functions as varied as motor control and drug addiction. 1,2 In many of these functions, dopamine clearly plays a variety of roles. Such diversity of effect is the result of dopamine's interaction with at least 3 distinct receptors designated D1, D2 and D3.3,4,5 These roles include immediate effects such as the control of movement and are most clearly demonstrated when a patient with Parkinson's disease takes L-Dopa and within minutes is able to move about easily. Dopamine is apparently also involved in long-term changes. For example, enduring changes in behaviour occur following exposure to psychostimulant drugs such as cocaine and amphetamine, which affect dopaminergic and other monoaminergic systems. These behavioral changes can occur after only a few exposures to the drug and can persist for many years. ${ }^{2}$ How does dopamine exert such long-term effects? A possible answer to this question comes from the discovery that dopamine and dopaminergic agonists of both the directly-acting type (such as apomorphine and bromocriptine) and the indirectly-acting type (such as amphetamine and cocaine) induce expression of a family of genes called immediate early genes. 6,7 These immediate early genes encode transcriptional activating (or inhibiting) factors that then alter the expression of other genes. Although it has not yet been conclusively demonstrated, these alterations in gene expression may underlie long-term change. $8,9,10,11$

Here we briefly review work on activation of $c-f o s$ and other immediate early genes by dopaminergic mechanisms.

\section{Activation of $c$-fos and Other Immediate Early Genes by Directly-acting Dopaminergic Agonists}

In general, it appears that directly acting dopamine agonists will induce $c$-fos expression only in tissue containing supersensitive dopamine receptors. ${ }^{6.7}$ Moreover, of the D1 and D2 agonists so far examined, only agonists of the D1-type appear to

From the Department of Pharmacology, Dalhousie University, Halifax, (H.A.R., M.L.P.) and the Department of Brain and Cognitive Sciences, Massachusetts Institute of Technology, Cambridge (R.M., A.M.G.)

Reprint requests to: Dr. H.A. Robertson, Department of Pharmacology, Faculty of Medicine, Dalhousie University, Halifax, Nova Scotia, Canada $\mathrm{B} 3 \mathrm{H} 4 \mathrm{H} 7$ 
produce this activation. ${ }^{7}$ In the rat, the dopaminergic neurotoxin, 6-hydroxydopamine, when injected into the substantia nigra on one side, will denervate dopamine innervated structures on that side. In such animals, L-Dopa and the DI-selective agonists SKF 38393 and CY 208-243 produce a rapid increase in production of nuclear immunostaining for Fos protein in medium-sized neurons throughout the caudate-putamen. ${ }^{6,7}$ Fos-like immunostaining is seen after as little as 30 minutes and persists for $6-10$ hours. In many systems, the Fos protein is only present for $2-4$ hours; Fos-related antigens of undetermined functions may account for the immunostaining seen at longer survival times.

There is also a clear relationship between the degree of receptor supersensitivity and activation of $c$-fos expression. ${ }^{6}$ These unilaterally-6-OHDA-treated rats turn rapidly when given dopaminergic drugs, and this rotational behaviour can be used to assess the degree of supersensitivity of the dopamine receptors. Animals with incomplete lesions do not turn as rapidly as those with complete lesions. Similarly, animals with incomplete lesions show little or no Fos immunostaining while those which turn rapidly exhibit dramatic staining for Fos. Infusion of D1dopamine agonists directly into the striatum of normal rats has no effect of $c$-fos expression. ${ }^{12}$ However, if the animals have been depleted of dopamine with either the dopaminergic neurotoxin 6-hydroxydopamine or the monamine depleting drug reserpine, such direct infusions of Dl agonists produce a robust $c$-fos activation. 12

It is most important to note that Fos production is independent of rotation per se. We know this because we can dissociate rotation and $c$-fos activation in several ways. ${ }^{7}$ First, although dopamine agonists of both D1 and D2 types produce similar amounts of rotation in unilaterally denervated animals, only D1 agonists activate $c$-fos expression in the caudoputamen. Second, DI-agonist induced Fos production is observed in animals that are anaesthetized prior to receiving the D1-agonist. Thirdly, rats will also rotate towards the denervated side if a D1-agonist is injected into the substantia nigra on the lesioned side; in such animals, there is no activation of $c$-fos in the caudoputamen. ${ }^{7}$

As only D1-selective agonists activate c-fos in vivo, and the D1 dopamine receptor has traditionally been associated with adenylyl cyclase, it was not surprising to find that infusion of the directly-acting adenylyl cyclase activator forskolin into the striatum in rats produced a robust activation of Fos synthesis. ${ }^{12}$

Immunostaining for Fos occurs in medium sized neurons that make up more than $90 \%$ of striatal neurons. Retrograde tracer studies suggest that many of the neurons expressing $c$-fos in response to DI agonist stimulation project to the substantia nigra. ${ }^{13}$ At present, the characteristics of the Fos positive neurons are incompletely understood and studies are under way to determine whether these neurons also contain such D1 receptor markers as DARPP-32 and which neuropeptides they express.

Interestingly, whether a rat is newly treated with 6-OHDA or had been treated with 6-OHDA 9 months previously, the Fos immunostaining after L-Dopa challenge seems similar. ${ }^{5}$ By extrapolation, this suggests that patients with Parkinson's disease who take L-Dopa up to 4 times/day for years and often for decades may be activating $c$-fos gene expression with each dose.

What might the consequences of this continued, repeated activation of immediate early genes be? One possibility is that this activation might be associated with the development of dyskinesias. Evidence from non-human primate models of Parkinson's disease suggests that dyskinesias are associated largely, if not exclusively, with D1-type agonist treatment.14 Why, then, do some patients not develop dyskinesias when treated with L-Dopa? It may be that the patients who do not develop dyskinesias are incompletely denervated and do not produce Fos in response to the L-Dopa. The relationship between the activation of immediate early genes and development of dyskinesias needs to be explored further in animal models.

\section{Activation of $c$-fos and Other Immediate Early Genes by Indirectly-acting Dopaminergic Agonists}

Indirect dopamine agonists such as d-amphetamine and cocaine, which act to increase levels of endogenous dopamine, also activate the $c$-fos gene. However, there is a marked difference between the Fos response to direct and indirect agonists. Both amphetamine and cocaine induce expression of Fos protein in the intact striatum as well as in the 6-OHDA-denervated striatum of rats unilaterally lesioned with 6-OHDA.7.15.16,17 In fact, in 6-OHDA-treated rats, the preponderance of Fos-like immunoreactivity is found on the intact side following indirect agonist treatment. ${ }^{7}$ Interestingly, despite the fact that the effects of cocaine and amphetamine are in many ways indistinguishable behaviorally, these psychostimulant drugs produce strikingly different patterns of $c$-fos expression in the striosome-matrix compartments and limbic subdivisions of the striatum. ${ }^{17}$ Animals given cocaine $(25 \mathrm{mg} / \mathrm{kg}$, i.p.) show widespread activation of $c$-fos throughout the striatum 2 hours later. In contrast, animals given injections of $5-10 \mathrm{mg} / \mathrm{kg}$, i.p. of amphetamine and examined for striatal Fos-like immunoreactivity 2 hours later exhibit a vividly patchy pattern of $c$-fos expression. By comparing adjacent sections stained immunochemically for Fos-like immunoreactivity and calbindin $\mathrm{D}_{28 \mathrm{~K}}$-like immunoreactivity, it was possible to show that the Fos-positive patches correspond to the calbindin-poor striosomes.

The striosomes and matrix are the major neurotransmitterspecific compartments of the caudoputamen and have different input-output connections. 18.19.20,21.22 Striosomes and matrix are known to differ markedly in several important dopaminergic characteristics. For example, they have different levels of binding of D1 and D2 dopamine receptor-specific ligands, ${ }^{25}$ and monoamine uptake-site ligands, ${ }^{26,27}$ and they have different dopaminergic innervation. ${ }^{28,29,30}$ Interestingly, cocaine-induced Fos accumulation is completely eliminated by reserpinization of the animals whereas amphetamine-induced Fos accumulation remains intact. These findings raise the possibility that there may be a relationship between reserpine-sensitive and reserpineinsensitive pools of releasable catecholamines ${ }^{23}$ and psychostimulant induction of $c$-fos. ${ }^{24}$

The differential effects of cocaine and amphetamine on $c$-fos activation could conceivably relate to the different behavioural effects that these psychostimulant drugs produce. ${ }^{31}$ Although cocaine and amphetamine have many common features in terms of behaviour and neurotransmitter release, they do differ in some very significant ways, including neurotoxicity. ${ }^{32}$ Amphetamine and related compounds have marked neurotoxic effects, whereas cocaine appears to be devoid of such effects. 
This idea has been reinforced by the finding that NMDA receptors play a role in D1 dopamine-mediated c-fos activation; 33 it is known that the NMDA receptor plays a role in amphetamine neurotoxicity. 32

\section{Activation of $c$-fos and Other Immediate Early Genes by Dopamine Receptor Antagonists}

The finding that haloperidol and related D2 dopamine receptor antagonists will activate $c$-fos expression throughout the striatum was surprising, 34,35 especially as the simplest explanation (increased dopamine release following autoreceptor inhibition) seems unlikely as the D1 receptor antagonist SCH 23390 will not prevent D2 antagonist-induced activation of $c$-fos. ${ }^{34}$ This strengthens the idea that there is normally a tonic D2 mediated inhibition of $c$-fos expression in the striatum. Moreover, the induction of $c$-fos expression can be overcome by administration of the D2-selective agonist LY-171555, as would be expected if this were an effect mediated by D2 dopamine receptors. 35

\section{New Developments}

Fos and other products of immediate early genes act as parts of DNA complexes. ${ }^{9}$ Fos itself is active in heterodimeric association with the protein products of $c-j u n$ and other members of the jun family, but is not active, at least in vitro, in homodimeric Fos-Fos complexes. For striatal Fos induced by dopaminergic drugs to be functional, other immediate early genes need to be stimulated in the striatum, or there must be constituitive expression of such genes. In situ hybridization evidence suggests that jun-B and other immediate early genes are indeed activated by cocaine and amphetamine. ${ }^{36,37,38,39}$ Interestingly, though high levels of striatal jun-B mRNA transcripts are induced by these drugs, $c$-jun mRNA transcripts are barely detectable at 1 hour post-injection. This suggests that specific patterns of transcriptional factor activation may be involved in the response of individual cell types to particular stimulations.

The work of Hunt and his colleagues ${ }^{40}$ was the first to suggest that $c$-fos activation might serve as a functional tracing technique with cellular resolution. This potential has been borne out by many findings including those on the dopaminergic system. One interesting application of this approach has been the use of $c$-fos to map out functional interactions between grafted and host tissue in the striatum. 41,42 Amphetamine and cocaine induce strong $c$-fos expression in neurons of intrastriatal grafts derived from embryonic rat striatal primordia and implanted into previously excitotoxin-damaged striatum of host rats. The induction is specific in that it is located in the regions of the grafts that have striatal characteristics and that project to the pallidum ${ }^{43-45}$ Thus, the $c$-fos activation may be indicative of functionally-specific graft-host interactions.

In addition to using Fos activation as a technique to study responses to systemically administered drugs, we have studied the response of $c-$ fos following direct infusions of drugs into the striatum. 12 This procedure has many advantages and permits use of compounds that do not cross the blood-brain barrier. ${ }^{12}$

The most important question to be answered now is what is the role of $c$-fos and other immediate early genes in dopaminergic function in the striatum. We have suggested the possibility that such long-term changes as priming, 7,46,47 drug addiction ${ }^{17}$ and dyskinesias ${ }^{7}$ might be related in some way to dopamine receptor mediated $c$-fos activation. The molecular mechanisms by which these changes are achieved remain to be determined. In other systems, $c$-fos and related immediate early genes appear to regulate synthesis of peptides and proteins such as enkephalin ${ }^{48}$ and nerve growth factor. ${ }^{49}$ Understanding of the role that the immediate early genes play in the basal ganglia will give us important insights into the function of this extensive neural system of the forebrain.

\section{ACKNOWLEDGEMENTS}

Our work has been supported by grants to HAR from the Medical Research Council of Canada (grant MA 10644), and Sandoz (Canada) Inc., by grants to AGM from NARSAD, the Scottish Rite Schizophrenia Research Program and NINDS (award NS 25529), and by a joint grant to AMG and HAR from the Human Frontiers Science Program.

\section{REFERENCES}

1. Hornykiewicz O. The mechanisms of action of L-dopa in Parkinson's disease, Life Sci 15 1974; 1249-1259.

2. Koob GF, Bloom FE. Cellular and molecular mechanisms of drug dependence. Science 1988; 242: 715-723.

3. Kebabian JW, Calne, DB. Multiple receptors for dopamine. Nature 1979; 277: 93-96.

4. Robertson GS, Robertson HA. D1 and D2 dopamine agonist synergism: separate sites of action. Trends Pharmacol Sci 1987; 8: 295-299.

5. Sokoloff P, Giros B, Martres M-P, et al. Molecular cloning and characterization of a novel dopamine receptor $\left(\mathrm{D}_{3}\right)$ as a target for neuroleptics. Nature 1990; 347: 146-151.

6. Robertson GS, Herrera DG, Dragunow M,et al. L-Dopa activates cfos expression in the striatum of 6-hydroxydopamine-lesioned rats. Eur J Pharmacol 1989; 159: 99-100.

7. Robertson HA, Peterson MR, Murphy K, et al. D1 dopamine receptor agonists selectively activate striatal $c$-fos independent of rotational behaviour. Brain Research 1989; 503: 346-349.

8. Berridge MJ. Second messenger dualism in neuromodulation and memory. Nature 1986; 323: 294-295.

9. Morgan JI, Curran T. Stimulus-transcription coupling in neurons: role of cellular immediate-early genes. Trends Neurosci 1989; 12: 459-462.

10. Dragunow M, Currie RW, Faull RLM, et al. Immediate-early genes, kindling and long-term potentiation, Neurosci and Biobehav Rev 1989; 13: 301-312.

11. Robertson HA, Dragunow M. From synapse to genome: the role of immediate-early genes in permanent alterations in the central nervous system. In: N.N. Osborne ed., Macmillan Press Lid.; 1990: 143-157.

12. Robertson HA, Graybiel AM, Paul ML. Activation of rat striatal cfos by direct infusion of dopamine agonists and forskolin. Soc Neurosci Abstr 1990; 16: 1232.

13. Robertson GS, Vincent SR, Fibiger HC. Striatonigral projection neurons contain DI dopamine receptor-activated $c$-fos Brain Research 1990; 523: 288-290.

14. Bedard PJ, Di Paola T, Falardeau P, et al. Chronic treatment with levodopa but not bromocriptine induces dyskinesia in MPTPtreated monkeys. Correlation with ${ }^{3} \mathrm{H}$-spiperone binding. Brain Res 1986; 379: 294-299.

15. Johnson K, Robertson HA. The NMDA antagonist MK-801 reverses D-amphetamine-induced activation of the proto-oncogene $c$-fos in rat striatum. Soc Neurosci Abstr 1989; 15: 782.

16. Young ST, Porrino LJ, Iadarola MJ. Induction of $c$-fos by direct and indirect dopamine agonists. Soc Neurosci Abstr 1989; 15: 1091.

17. Graybiel AN, Moratalla R, Robertson HA. Amphetamine and cocaine induce drug-specific activation of the $c$-fos gene in striosome-matrix and limbic subdivisions of the striatum. Proc Natl Acad Sci USA 1990; 87 (1990) 6912-6916. 
18. Graybiel AM, Ragsdale CW Jr. Histochemically distinct compartments in the striatum of human, monkey and cat demonstrated by acetylcholinesterase staining. Proc Natl Acad Sci USA 1978; 75: $5723-5726$

19. Graybiel AM. Dopaminergic and cholinergic systems in the striatum. In: Crossman A, Sambrook MA, eds. "Neural Mechanisms in Disorders of Movement", London: Libbey 1989: 3-15.

20. Gerfen CR. The neostriatal mosaic: striatal patch-matrix organization is related to cortical lamination. Science 1989; 246: 385-388.

21. Donoghue JP, Herkenham M. Neostriatal projection from individual cortical fields conform to histochemically distinct compartments in the rat. Brain Research 1986; 365: 397-403.

22. Graybiel AM. Neurotransmitters and neuromodulators in the basal ganglia. Trends Neurosci 1990; 13: 244-254.

23. Glowinski J, Iversen LL, Axelrod J. Storage and synthesis of norepinephrine in the reserpine-treated rat brain. J Pharmacol Exp Ther 1966; 151: 385-399.

24. McMillan BA. CNS stimulants: two distinct mechanisms of action for amphetamine-like drugs. Trends Pharmacol Sci 1983; 4: 429 432.

25. Besson M-J, Graybiel AM, Nastuk M. [3H]-SCH23390 binding to -D1 dopamine receptors in the basal ganglia of the cat and primate: delineation of striosomal compartments and pallidal and nigral subdivisions. Neuroscience 1988; 26: 101-119.

26. Graybiel AM, Moratalla R. Dopamine uptake sites in the striatum are distributed differentially in striosome and matrix compartments. Proc Natl Acad Sci USA 1989; 86: 9020-9024.

27. Lowenstein PR, Joyce JN, Coyle JT, et al. Striosomal organization of cholinergic and dopaminergic uptake sites and cholinergic $M_{1}$ receptors in the adult human striatum: a quantitative receptor autoradiographic study. Brain res 1990; 510: 122-126.

28. Olson L, Seiger A, Fuxe K. Heterogeneity of striatal and limbic dopamine innervation: highly fluorescent islands in developing and adult rats. Brain Res 1972; 44: 283-288.

29. Gerfen CR. The nigrostriatal mosaic: compartmentalization of corticostriatal input and striatonigral output. Nature 1984; 311 : $46 !-464$.

30. Jimenez-Castellanos J,Graybiel AM. Compartmental origins of striatal efferent projections in the cat. Neuroscience 1987; 32: 223242.

31. Porrino LJ, Ritz MC,Goodman NL, et al. Differential effects of the pharmacological manipulation of serotonin systems on cocaine and amphetamine self-administration in rats. Life Sci 1989; 45: 1529-1535.

32. Sonsalla PK, Nicklas WJ, Heikkila RE Role for excitatory amino acids in methamphetamine-induced nigrostriatal dopaminergic toxicity. Science 1989; $243: 398-400$.

33. Paul ML, Graybiel AM, Robertson HA. Synergistic activation of the immediate-early gene $c$-fos in striosomes by D1- and D2selective agonists, Soc Neurosci Abstr 1990; 16: 954.
34. Dragunow M, Robertson GS, Faull RLM, et al. Haloperidol induces an accumulation of $c$-fos-like protein in rat striatal neurons: NMDA receptor mediation, Neuroscience 1990; 37: 287-294.

35. Miller JC. Induction of $c$-fos mRNA expression in rat striatum by neuroleptic drugs. J Neurochem 1990; 54: 1453-1455.

36. Moratalla R, Robertson HA, Graybiel AM. Parallel induction of jun-b and $c$-fos evoked in the striatum by the psychomotor stimulant drugs cocaine and amphetamine. Soc Neurosci Abstr 1990; 16: 954.

37. Cohen BM, Van Nhuyen T, Babb SM, et al. Cocaine induces rapid expression of $c$-fos and zif/268 in rat brain. Soc Neurosci Abstr $1990 ; 16: 745$

38. Cole AJ, Worley PF, Baraban JM. Dopaminergic regulation of transcript factor mRNAs in striatal neurons in vivo. Soc Neurosci Abstr 1990; 16: 800.

39. Iadarola MJ, Yeung CL, Hoo Y, et al. Elevation of striatal $c$-fos and API complex formation after treatment with cocaine. Soc Neurosci Abstr 1990; 16: 1277.

40. Hunt SP, Pini A, Evan G. Induction of $c$-fos-like protein in spinal cord neurons following sensory stimulation. Nature 1987; 328 : 632-634.

41. Liu F-U, Dunnett SB, Robertson HA, et al. Intrastriatal grafts derived from fetal striatal primordia. III. Induction of the immediate early gene $c$-fos by cocaine. Exp Brain Res (in press).

42. Cenci MA, Mandel RJ, Kalen P, et al. c-fos induction in intrastriatal grafts of fetal nigral and striatal tissue: functional role of DI dopamine receptors in graft-host interactions. Soc Neurosci Abstr 1990; 15: 469.

43. Graybiel AM, Liu F-C, Dunnett SB. Intrastriatal grafts derived from fetal striatal primordia. I. Phenotypy and modular organization. J Neurosci 1989; 9: 3250-3270.

44. Liu F-C, Graybiel AM, Dunnett SB, et al. Intrastriatal grafts derived from fetal striatal primordia: II. Reconstitution of cholinergic and dopaminergic systems. J Comp Neurol 1990; 295: 114.

45. Wictorin K, Simerly RB, Isacson O, et al. Connectivity of striatal grafts implanted into the ibotenic acid lesioned striatum-III. Efferent projecting graft neurons and their relations to host afferents within the grafts. Neuroscience 1989; 30: 313-330.

46. Morelli M, Fenu S, Di Chiara G. Behavioural expression of D1receptor supersensitivity depends on previous stimulation of D-2 receptors. Life Sci 1987; 40: 245-251.

47. Paul ML, Graybiel AM, Robertson HA in preparation.

48. Sonnenberg JL, Rauscher FJ III, Morgan JI, et al. Regulation of proenkephalin by Fos and Jun. Science 1989; 246: 1622-1625.

49. Hengerer $B$, Lindholm D, Heumann $R$, et al. Lesion-induced increase in nerve growth factor mRNA is mediated by $c$-fos. Proc Natl Acad Sci USA 1990; 87: 3899-3903. 